Original Article

\title{
Determinan Kesediaan Masyarakat Menerima Vaksinasi Covid-19 di Sulawesi Tengah
}

\section{Determinants of Community Willingness to Receive Covid-19 Vaccination in Central Sulawesi}

\author{
Dewi Susetiyany Ichsan ${ }^{1 *}$, Fahmi Hafid ${ }^{2}$, Kadar Ramadhan ${ }^{2}$, Taqwin ${ }^{2}$ \\ ${ }^{1}$ Balai Pengawas Obat dan Makanan Kota Palu \\ ${ }^{2}$ Poltekkes Kemenkes Palu \\ (dewi.hafid@yahoo.com)
}

\begin{abstract}
ABSTRAK
Tujuan penelitian untuk mengetahui determinan kesediaan masyarakat menerima vaksinasi Covid-19 di Sulawesi Tengah. Metode penelitian berupa penelitian deskriptif analitik dengan desain cross sectional. Survei online masyarakat di Sulawesi Tengah dengan 266 orang responden berusia 18 tahun ke atas. Analisis statistic menggunakan uji chi square dan regresi logistic dengan kemaknaan pvalue $0,05 \%$. Hasil penelitian menunjukkan responden yang bersedia menerima vaksinasi Covid-19 sebesar 35,3\%. Faktor yang mempengaruhi kesediaan masyarakat Sulawesi Tengah menerima vaksinasi adalah faktor umur, tingkat pendidikan, pekerjaan, status pernikahan, agama dan suku. Determinan kesediaan masyarakat menerima vaksinasi Covid-19 adalah umur dan agama. Kesimpulan, responden yang bersedia menerima vaksinasi Covid-19 sebesar 35,3\% dengan determinan umur dan agama. Disarankan agar sosialisasi untuk divaksinasi Covid-19 fokus pada orang dengan kelompok umur $\leq 40$ tahun dan beragama Islam. Sosialisasi vaksinasi Covid-19 melalui televisi dan media sosial facebook dan Instagram oleh satgas Covid-19, Badan PengawasObat dan Makanan dan Kementerian Kesehatan.
\end{abstract}

Kata kunci: Determinan kesediaan, vaksinasi, Covid-19

\section{ABSTRACT}

This study aims to determine the community's willingness to receive Covid-19 vaccination in Central Sulawesi. This study was an analytical descriptive study with cross sectional design in January 2021. Online survey accindental sampling was conducted for people in Central Sulawesi aged 18 years and above. Data were analyzed using SPSS 22.0, chi square test and logistic regression the significance of p-value is $0.05 \%$. Study findings showed that Respondents who have health insurance (BPJS) were $80.5 \%$. Covid-19 prevention behaviors practiced by the community includes; using face mask (99.6\%), distancing (95.9\%), avoiding crowds (95.5\%) and washing hands using soap in running water (96.2\%). Respondents who were willing to receive Covid-19 vaccination were 35.3\%. Factors affecting the willingness of the people of Central Sulawesi to receive vaccinations were age, education level, occupation, marital status, religion and ethnicity. The determinants of people's willingness to receive Covid-19 vaccination were age and religion. Conclusion, respondents who were willing to receive Covid-19 vaccination were $35.3 \%$ and the main determinants were age and religious belief. It is recommended that the socialization for Covid-19 vaccination focuses on people in the $\leq 40$ years age group and muslims. Covid-19 vaccination dissemination needs to be intensified through television and social media facebook and Instagram by the Covid-19 task force, the Food and Drug Administration and the Ministry of Health.

\section{Key words: Determinants of Willingness, Vaccination, Covid-19}

https://doi.org/10.33860/jik.v15i1.430 


\section{PENDAHULUAN}

Vaksin merupakan solusi terakhir untuk penyakit menular ${ }^{1}$. Hambatan utama penggunaan vaksin Covid-19 adalah keraguan masyarakat terhadap vaksin ${ }^{2}$. Persepsi masyarakat tentang keamanan dan efektifitas vaksin Covid-19 harus baik. Persepsi masyarakat merupakan suatu proses ulang yang dialami oleh manusia pada suatu lingkungan tertentu dan memberikan pengetahuan atau gagasan yang positif dan negatif kepada masyarakat sekitar. Kehadiran virus jenis baru yang belum ditemukan obatnya ini membuat masyarakat cemas, ketakutan, dan bahkan depresi ${ }^{3}$.

Penyakit Coronavirus 2019 dinyatakan sebagai pandemi pada Maret 2020. Beberapa vaksin profilaksis Covid-19 terus dikembangkan, tetapi kesediaan individu menerima vaksin Covid-19 kurang diketahui ${ }^{4}$. Kepercayaan publik terhadap program vaksinasi bergantung pada pemerintah. Program Kesehatan masyarakat harus lebih luas daripada penyampaian teknologi vaksin ${ }^{5}$. Studi terhadap mahasiswadi China menunjukkan bahwa responden memiliki persepsi risiko tinggi terhadap Covid-19. Mahasiswa perempuan, mahasiswa non kedokteran, mahasiswa yang sekolahnya berlokasi di Hubei dan mahasiswa dengan tingkat pengetahuan yang lebih tinggi memiliki persepsi risiko yang lebih tinggi ${ }^{6}$. Studi Zhu dkk menyatakan vaksin Covid-19 aman dan telah menyebabkan respons imun yang signifikan setelah imunisasi tunggal di sebagian besar penerima ${ }^{7}$. Masyarakat diharapkan lebih tahu untuk menilai vaksin baru yang sedang diproduksi ${ }^{8}$. Sementara sejumlah vaksin sedang dikembangkan, vaksin yang efektif untuk Covid19 diharapkan telah tersedia untuk umum pada tahun 2021. Untuk itu upaya memfasilitasi penerimaan, memastikan kepercayaan publik terhadap keamanan dan kemanjuran vaksin menjadi sangat penting 9 .

Sebuah penelitian di Prancis menunjukkan bahwa $75 \%$ responden menerima vaksin dan 48\% berpartisipasi dalam uji klinis Covid- $19^{2}$.

Dapat ditambahkan penelitian terdahulu terkait varibel yg diangkat pada penelitian ini.

Dalam konteks wilayah, belum diketahuinya determinan kesediaan masyarakat menerima vaksinasi Covid-19 di Sulawesi
Tengah mendasari penelitian ini dilaksanakan. Penelitian ini bertujuan untuk mengetahui determinan kesediaan masyarakat menerima vaksinasi Covid-19 di Sulawesi Tengah.

\section{METODE PENELITIAN}

Penelitian deskriptif analitik desain cross sectional pada bulan Januari tahun 2021. Populasi adalah masyarakat Sulawesi Tengah dengan jumlah sampel sebanyak 266 orang dengan metode accidental sampling. Kuesioner hanya ditujukan kepada responden yang berusia 18 tahun ke atas. Mengingat kondisi pandemic, pengumpulan data dilakukan secara elektronik melalui google formulir pada kuesioner https://ee.kobotoolbox.org/x/aSWgcPdw. Form pernyataan persetujuan keikutsertaan dalam survei dinyatakan dalam kueisoner online yang dibagikan.

Dijelaskan variabel yang diteliti, indikator serta sumbernya Kelayakan etik penelitian diperoleh dari Poltekkes Kemenkes Palu dengan nomor LB.01.01/KE/0017/V/2021. Entri dan analisis data menggunakan SPSS 22,0. Analisis data secara bivariat dan multivariat. Uji yang digunakan adalah uji $c h i$ square dan regresi logistik pada kemaknaan $p$ value $0,05 \%$. Data disajikan dalam bentuk tabel dan diagram.

\section{HASIL}

Hasil penelitian menunjukkan partisipasi responden sebanyak 266 orang dengan karakteristik; responden yang berjenis kelamin laki-laki sebanyak 32,0\%, berumur 20-40 tahun sebanyak $31,2 \%$, berpendidikan tinggi $39,5 \%$, berstatus pelajar atau mahasiswa sebanyak $33,5 \%$. Bekerja sebagai aparatur sipil negara PNS/TNI/Polri sebanyak 23,3\%. status menikah $51,9 \%$, beragama Islam $80,8 \%$, suku bugis $24,4 \%$ dan berada di wilayah perkotaan $52,6 \%$. Responden yang telah memiliki BPJS $80,5 \%$. Responden yang bersedia menerima vaksinasi Covid-19sebanyak 35,3\%. Perilaku pencegahan penularan Covid-19 oleh responden meliputi; penggunaan masker 99,6\% menjaga jarak 95,9\% menghindari kerumunan 95,5\% dan mencuci tangan menggunakan sabun pada air mengalir sebanyak $96,2 \%$. Responden yang meyakini keamanan dan efektifitas vaksin 
Covid-19 sebanyak 79,3\%, menyatakan tidak aman $11,7 \%$ menyatakan tidak efektif $4,9 \%$ menyatakan takut efek samping 13,5\% dan bertentangan nilai agama sebanyak 1,1\%. Faktor yang mempengaruhi kesediaan masyarakat menerima vaksinasi Covid-19 di Sulawesi Tengah adalah umur, tingkat pendidikan,pekerjaan, status pernikahan, agama, suku. Determinan kesediaan masyarakat menerima vaksinasi Covid-19 adalah faktor umur (p-value $=0,000 \quad \mathrm{OR}=0,423(0.277-0.648)$ dan agama ( $\mathrm{p}$-value $=0,000 \mathrm{OR}=0,402(0.241$ $0.670)$.

Tabel 1. Karakteristik Responden tentang Kesediaan Masyarakat Menerima Vaksinasi Covid-19 di Sulawesi Tengah

\begin{tabular}{lcr}
\hline \multicolumn{1}{c}{ Karakteristik } & n & \% \\
\hline Jenis Kelamin & & \\
Laki-Laki & 85 & 32,0 \\
Perempuan & 181 & 68,0 \\
Kelompok Umur (tahun) & & \\
<20 & 67 & 25,2 \\
20-40 & 83 & 31,2 \\
41-60 & 55 & 20,7 \\
>60 & 61 & 22,9 \\
Pendidikan & & \\
Pendidikan Dasar & 60 & 22,6 \\
Pendidikan Menengah & 101 & 38,0 \\
Pendidikan Tinggi & 105 & 39,5 \\
Pekerjaan & & \\
Pelajar/mahasiswa & 89 & 33,5 \\
PNS/TNI/POLRI & 62 & 23,3 \\
Pegawai swasta & 11 & 4,1 \\
Wiraswasta & 18 & 6,8 \\
Petani & 35 & 13,2 \\
Nelayan & 2 & 0,8 \\
Buruh harian/sopir & 2 & 0,8 \\
Pembantu rumah tangga & 9 & 3,4 \\
Lainnya & 38 & 14,3 \\
Status Pernikahan & & \\
Belum menikah & 104 & 39,1 \\
Menikah & 138 & 51,9 \\
Janda/Duda & 24 & 9,0 \\
Agama & & \\
Islam & 215 & 80,8 \\
Kristen Protestan & 43 & 16,2 \\
Kristen Katolik & 2 & 0,8 \\
Hindu & 6 & 2,3 \\
Suku & & \\
Kaili & 34 & 12,8 \\
Kulawi & 2 & 0,8 \\
Pamona & 29 & 10,9 \\
Mori & 11 & 4,1 \\
Bungku & 1 & 0,4 \\
& & \\
& &
\end{tabular}

\begin{tabular}{lcr} 
Saluan & 11 & 4,1 \\
Buol & 6 & 2,3 \\
Toli-toli & 3 & 1,1 \\
Jawa & 40 & 15,0 \\
Bali & 7 & 2,6 \\
Bugis & 65 & 24,4 \\
Lainnya & 57 & 21,4 \\
mpat tinggal & & \\
Perkotaan & 140 & 52,6 \\
Pedesaan & 126 & 47,4 \\
pemilikan BPJS & & \\
$\quad$ Ya & 214 & 80,5 \\
Tidak & 52 & 19,5 \\
sediaan menerima & & \\
sinasi Covid-19 & & \\
Bersedia & 94 & 35,3 \\
Tidak/belum bersedia & 172 & 64,7 \\
\hline
\end{tabular}

Grafik 1 menunjukkkan bahwa responden yang meyakini keamanan dan efektifitas vaksin Covid-19 sebanyak 79,3\%, menyatakan tidak aman $11,7 \%$ menyatakan tidak efektif $4,9 \%$ menyatakan takut efek samping $13,5 \%$ dan yang menyatakan bertentangan nilai agama sebanyak $1,1 \%$. Sementara itu dari grafik 2 menunjukkan bahwa responden memperoleh informasi tentang Covid-19 dari Satgas Covid-19, dari Badan POM dan dari Kemenkes sebanyak 40,2\% melalui televisi 53,8\%, facebook $(27,4 \%)$ dan Instagram $(23,7 \%)$.

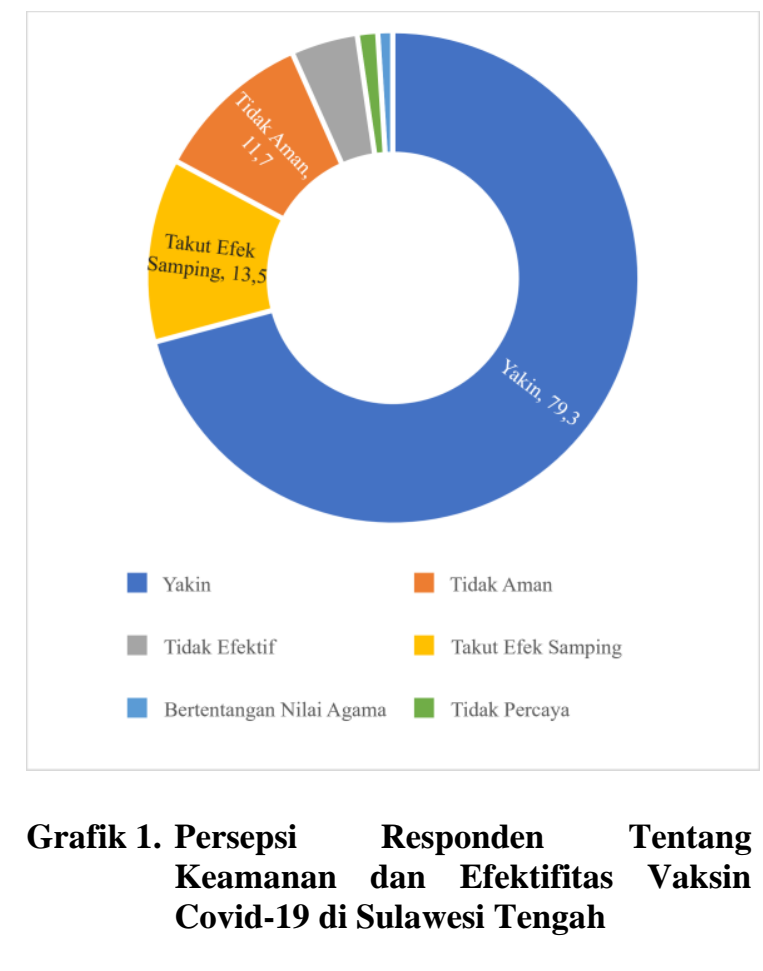


Analisis bivariat chi-square menunjukkan bahwa faktor yang mempengaruhi kesediaan masyarakat menerima vaksinasi Covid-19 Sulawesi Tengah adalah umur ( $\mathrm{p}$ value $=0,000)$ tingkat pendidikan ( $\mathrm{p}$ value $=0,006)$, pekerjaan $(\mathrm{p}$ value $=0,005)$, status pernikahan $(\mathrm{p}$ value $=$
$0,001)$, Agama ( $\mathrm{p}$ value $=0,012)$, suku ( $\mathrm{p}$ value $=0,003)$. Untuk melihat determinan kesediaan menerima vaksinasi, maka faktor faktor tersebut dianalisis lebih lanjut dengan analisis multivariat regresi logistik.

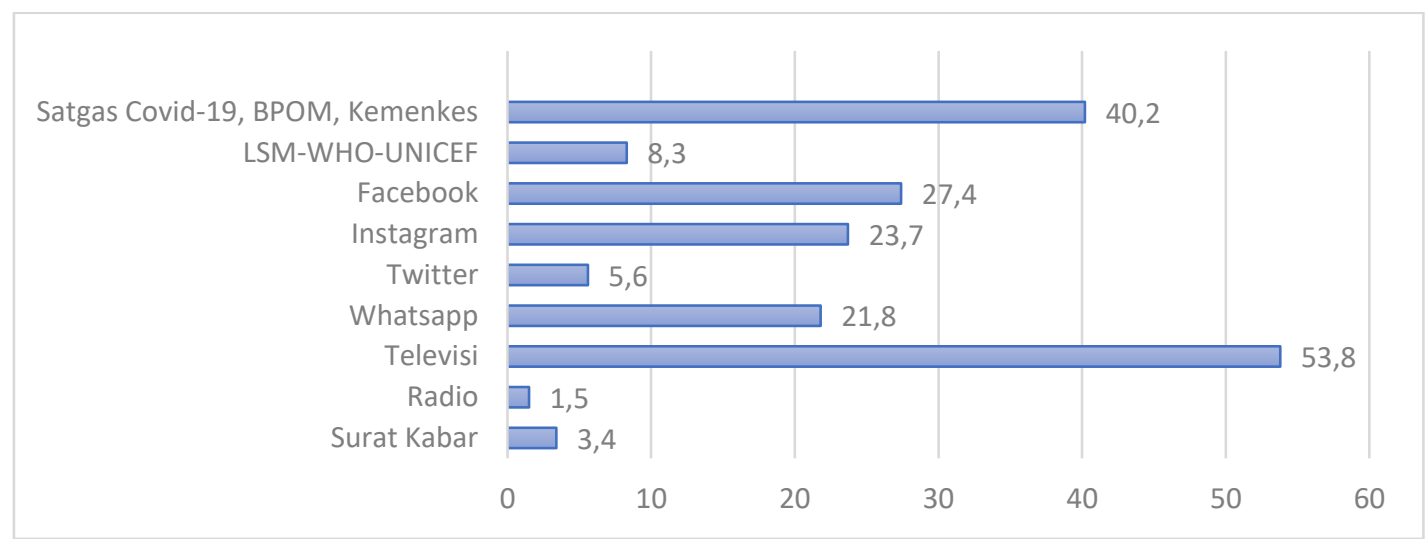

Grafik 2. Sumber informasi tentang Covid-19 yang diperoleh responden di Sulawesi Tengah

Tabel 2. Faktor-faktor yang Mempengaruhi Kesediaan Responden untuk Menerima Vaksinasi Covid19di Sulawesi Tengah

\begin{tabular}{|c|c|c|c|c|c|}
\hline \multirow{3}{*}{ Karakteristik } & \multicolumn{4}{|c|}{ Kesediaan divaksinasi Covid-19 } & \multirow{3}{*}{ p-value } \\
\hline & \multicolumn{2}{|c|}{ Bersedia } & \multicolumn{2}{|c|}{ Tidak/Belum Bersedia } & \\
\hline & $n=94$ & $35.3 \%$ & $\mathrm{n}=172$ & $64.7 \%$ & \\
\hline \multicolumn{6}{|l|}{ Jenis Kelamin } \\
\hline Laki-Laki & 33 & 38,8 & 52 & 61,2 & 0,415 \\
\hline Perempuan & 61 & 33,7 & 120 & 66,3 & \\
\hline \multicolumn{6}{|l|}{ Kelompok Umur (tahun) } \\
\hline$<20$ & 11 & 16,4 & 56 & 83,6 & \\
\hline $20-40$ & 28 & 33,7 & 55 & 66,3 & $0,000 *$ \\
\hline $41-60$ & 26 & 47,3 & 29 & 52,7 & \\
\hline$>60$ & 29 & 47,5 & 32 & 52,5 & \\
\hline \multicolumn{6}{|l|}{ Pendidikan Terakhir } \\
\hline Pendidikan Dasar & 28 & 46,7 & 32 & 53,3 & \multirow{3}{*}{0,006} \\
\hline Pendidikan Menengah & 24 & 23,8 & 77 & 76,2 & \\
\hline Pendidikan Tinggi & 42 & 40,0 & 63 & 60,0 & \\
\hline \multicolumn{6}{|l|}{ Pekerjaan } \\
\hline Pelajar/mahasiswa & 18 & 20,2 & 71 & 79,8 & \multirow{9}{*}{$0,005^{*}$} \\
\hline PNS/TNI/POLRI & 26 & 41,9 & 36 & 58,1 & \\
\hline Pegawai swasta & 7 & 63,6 & 4 & 36,4 & \\
\hline Wiraswasta & 7 & 38,9 & 11 & 61,1 & \\
\hline Petani & 19 & 54,3 & 16 & 45,7 & \\
\hline Nelayan & 0 & 0,0 & 2 & 100 & \\
\hline Buruh harian/sopir & 0 & 0,0 & 2 & 100 & \\
\hline Pembantu rumah tangga & 3 & 33,3 & 6 & 66,7 & \\
\hline Lainnya & 14 & 36,8 & 24 & 63,2 & \\
\hline \multicolumn{6}{|l|}{ Status Pernikahan } \\
\hline Belum menikah & 24 & 23,1 & 80 & 76,9 & \multirow{3}{*}{$0,001 *$} \\
\hline Menikah & 63 & 45,7 & 75 & 54,3 & \\
\hline Janda/Duda & 7 & 29,2 & 17 & 70,8 & \\
\hline
\end{tabular}




\begin{tabular}{|c|c|c|c|c|c|}
\hline \multirow{3}{*}{ Karakteristik } & \multicolumn{4}{|c|}{ Kesediaan divaksinasi Covid-19 } & \multirow{3}{*}{ p-value } \\
\hline & \multicolumn{2}{|c|}{ Bersedia } & \multicolumn{2}{|c|}{ Tidak/Belum Bersedia } & \\
\hline & $\mathrm{n}=94$ & $35.3 \%$ & $\mathrm{n}=\mathbf{1 7 2}$ & $64.7 \%$ & \\
\hline \multicolumn{6}{|l|}{ Agama } \\
\hline Islam & 66 & 30,7 & 149 & 69,3 & \\
\hline Kristen Protestan & 23 & 53,5 & 20 & 46,5 & $0,012 *$ \\
\hline Kristen Katolik & 1 & 50,0 & 1 & 50,0 & \\
\hline Hindu & 4 & 66,7 & 2 & 33,3 & \\
\hline \multicolumn{6}{|l|}{ Suku } \\
\hline Kaili & 9 & 26,5 & 25 & 73,5 & \\
\hline Kulawi & 1 & 50,0 & 1 & 50 & \\
\hline Pamona & 16 & 55,2 & 13 & 44,8 & \\
\hline Mori & 0 & 0 & 11 & 100 & \\
\hline Bungku & 0 & 0 & 1 & 100 & \\
\hline Saluan & 5 & 45,5 & 6 & 54,5 & $0,003 *$ \\
\hline Buol & 0 & 0 & 6 & 100 & \\
\hline Toli-toli & 2 & 66,7 & 1 & 33,3 & \\
\hline Jawa & 20 & 50,0 & 20 & 50,0 & \\
\hline Bali & 5 & 71,4 & 2 & 28,6 & \\
\hline Bugis & 17 & 26,2 & 48 & 73,8 & \\
\hline Lainnya & 19 & 33,3 & 38 & 66,7 & \\
\hline Tempat tinggal & 50 & 35,7 & & & \\
\hline Perkotaan & 44 & 34,9 & 90 & 64,3 & 0,892 \\
\hline Pedesaan & 94 & 35,3 & 82 & 65,1 & \\
\hline
\end{tabular}

Tabel 3. Determinan Kesediaan Masyarakat Menerima Vaksinasi Covid-19di Sulawesi Tengah

\begin{tabular}{lcccccc}
\hline \multicolumn{1}{c}{ Variabel } & B & S.E. & Sig. & $\operatorname{Exp(B)}$ & $\begin{array}{r}\text { 95\% C.I.for } \operatorname{Exp}(\mathbf{B}) \\
\text { Lower }\end{array}$ & Upper \\
\hline Umur & $-0,859$ & 0,217 & 0,000 & 0,423 & 0,277 & 0,648 \\
Tingkat pendidikan & $-0,266$ & 0,207 & 0,200 & 0,766 & 0,510 & 1,151 \\
Pekerjaan & 0,040 & 0,065 & 0,537 & 1,041 & 0,917 & 1,182 \\
Status pernikahan & 0,246 & 0,328 & 0,452 & 1,279 & 0,673 & 2,432 \\
Agama & $-0,912$ & 0,261 & 0,000 & 0,402 & 0,241 & 0,670 \\
Suku & $-0,020$ & 0,028 & 0,482 & 0,980 & 0,928 & 1,036 \\
Constant & 4,112 & 0,927 & 0,000 & 61,096 & & \\
\hline
\end{tabular}

Analisis multivariat uji regresi logistik menunjukkan bahwa faktor umur (p-value $=$ 0,000 OR $=0,423(0.277-0.648)$ dan agama (pvalue $=0,000$ OR $=0,402 \quad(0.241-0.670)$ merupakan determinan kesediaan masyarakat menerima vaksinasi Covid-19di Sulawesi Tengah.

\section{PEMBAHASAN}

Partisipasi 266 responden menunjukkan perempuan (68\%) yang ikut serta dalam penelitan ini lebih banyak dibanding responden yang berjenis kelamin laki-laki (32,0\%). Sekitar sepertiga dari seluruh responden berumur pada rentang usia produktif 20-40 tahun, berpendidikan tinggi berstatus pelajar atau mahasiswa. Seperempat dari seluruh responden bekerja sebagai aparatur sipil negara PNS/TNI/Polri dengan suku bugis. Lebih dari setengahnya telah menikah dan tinggal diwilayah perkotaan. Mayoritas responden beragama Islam dan telah memiliki kartu badan penyelenggara jaminan sosial. Responden yang bersedia menerima vaksinasi Covid-19 hanya sepertiga dari 266 responden atau hanya 35,3\%.

Hasil penelitian ini menunjukkan meskipun $79,3 \%$ responden telah meyakini keamanan dan efektifitas vaksin Covid-19 
namun yang bersedia untuk divaksinasi hanya sebagian saja. Jika dibandingkan dengan penelitian lain seperti di Kota Surabaya, responden yang setuju untuk divaksin covid 19 cukup tinggi yaitu $81,1 \%{ }^{10}$. Demikian pula di Prancis sebesar 75\%. Di Malaysia justru terdapat $74 \%$ orang yang mengkhawatirkan keamanan dan efektivitas vaksin Covid-19 ${ }^{11}$. Di Amerika, $69 \%$ peserta bersedia divaksinasi Covid-194 sedangkan di Arab Saudi sebesar $64,7 \%{ }^{12}$. Responden yang tertarik untuk divaksinasi Covid-19 adalah mereka yang berusia lebih tua, telah menikah, pendidikan pascasarjana atau lebih tinggi, warna Non-Saudi Arabia, dan bekerja di sektor pemerintahan ${ }^{12}$.

Faktor rendahnya kesediaan masyarakat Sulawesi Tengah untuk menerima vaksinasi Covid-19 di Sulawesi Tengah dipengaruhi oleh faktor adalah umur, tingkat pendidikan, pekerjaan, status pernikahan, agama dan suku.

Semakin tua umur semakin tinggi kesediaan untuk menerima vaksinasi, pada kelompok usia yang lebih muda terdapat kecenderungan untuk tidak atau belum bersedia divaksinasi. Sementara orang yang berusia 65 tahun ke atas biasanya mengalami penurunan yang signifikan dalam akses lokasi vaksinasi, oleh karena terbatasnya mobilitas ${ }^{13}$, sehingga pembuat kebijakan harus mengeksplorasi bagaimana jaringan lokasi vaksinasi yang diperluas ini dapat memfasilitasi kelompok usia lanjut. Kelompok muda yang tidak atau belum bersedia divaksinasi menjadi sasaran sosialisasi dan edukasi mengingat kelompok muda juga berisiko untuk terinveksi Covid-19 ${ }^{14}$. Peningkatan proporsi insiden Covid-19 yang berkelanjutan terjadi di antara anak-anak (usia 0-19) dan dewasa muda (usia 20-39) menunjukkan peningkatan peran dalam penyebaran penyakit selama epidemi. Kemungkinan reservoir penyakit tercipta dengan risiko meluas ke orang tua yang lebih rentan dan juga kepada mereka yang memiliki kondisi komorbiditas. Pesan sesuai usia yang paham media untuk meningkatkan kepatuhan mitigasi diantara kelompok usia vaksinasi yang kurang rentan, lebih mobile dan prioritas lebih rendah akan menjadi kebutuhan dan prioritas berkelanjutan untuk mengurangi insiden populasi secara keseluruhan ${ }^{15}$.

Penelitian ini juga menunjukkan bahwa responden memperoleh informasi tentang Covid-19 dari Satgas Covid-19, dari Badan POM dan dari Kemenkes sebanyak 40,2\% melalui televisi 53,8\%. Suatu aplikasi untuk mengedukasi masyarakat akan pentingnya vaksinasi Covid-19. Aplikasi ini meningkatkan kesadaran publik tentang pentingnya vaksinasi Covid-19dapat melihat secara visual negaranegara di mana vaksinasi lambat dan sulit untuk mengontrol penyebaran Covid-19. Aplikasi pendidikan vaksinasi Covid-19memberikan informasi yang memadai dan bukti penelitian berbasis ilmiah untuk mengedukasi warga. Untuk memastikan bahwa vaksinasi Covid-19 dapat mendapatkan respons tinggi, diperlukan seminar pendidikan vaksinasi Covid-19 untuk mengungkap informasi palsu dan juga memberikan informasi vaksinasi Covid-19 yang akurat kepada publik ${ }^{11}$.

Tingkat pendidikan juga merupakan faktor yang mempengaruhi kesediaan masyarakat untuk menerima vaksinasi Covid-19. Terdapat kecenderungan semakin rendah pendidikan semakin bersedia untuk yang menerima vaksinasi dan begitu pula sebaliknya, semakin tinggi tingkat pendidikan semakin tidak bersedia untuk divaksinasi. Secara umum perilaku pencegahan penularan Covid-19 oleh responden sudah baik perilaku penggunaan masker 99,6\% menjaga jarak 95,9\% menghindari kerumunan $95,5 \%$ dan mencuci tangan menggunakan sabun pada air mengalir sebanyak 96,2\%. Perilaku ini merupakan langkah efektif dalam pencegahan penularan Covid-19. Dalam konteks pandemi Covid-19, Perilaku seperti mencuci tangan secara teratur, menjaga jarak, dan memakai masker wajah sangat disarankan ${ }^{16}$. Studi Wong (2020) menunjukkan 98,8\% responden menggunakan masker untuk mencegah Covid-19, proporsi yang lebih tinggi daripada tindakan mencuci tangan ${ }^{17}$. Advokasi untuk memperluas penggunaan masker wajah di masyarakat, baik untuk pengendalian sumber maupun perlindungan individu, harus dipertimbangkan, terutama mengingat tingginya viral load pada pasien Covid-19 tanpa gejala atau gejala minimal ${ }^{18}$.

Penelitian ini juga menunjukkan bahwa responden yang meyakini keamanan dan efektifitas vaksin Covid-19 sebanyak 79,3\%, 
menyatakan tidak aman $11,7 \%$ menyatakan tidak efektif $4,9 \%$ menyatakan takut efek samping $13,5 \%$ dan responden yang menyatakan bertentangan nilai agama sebanyak $1,1 \%$. Keyakinan responden tentang keamanan dan efektifitas vaksin Covid-19 sudah cukup bagus, namun pada kelompok yang belum meyakini keamanan dan efektifitas vaksin Covid-19 ini perlu diberikan sosialisasi dengan pendekatan ilmiah dan pendekatan keagamaan.

Lebih lanjut hasil analisis determinan menunjukkan bahwa faktor umur dan agama merupakan determinan kesediaan masyarakat menerima vaksinasi Covid-19 di Sulawesi Tengah. Umur dan agama menjadi faktor kunci dari kesediaan masyarakat Sulawesi Tengah untuk menerima vaksinasi Covid-19. Oleh karena OR faktor umur $=0,423(0.277-0.648)$ ini berarti faktor umur menjadi determinan protektif kesediaan responden untuk menerima vaksinasi.

Keterlibatan dalam perilaku protektif menurun dengan bertambahnya usia dan bahwa orang dewasa yang lebih tua menunjukkan pola terhadap risiko yang dirasakan lebih rendah dibandingkan dengan orang dewasa paruh baya. Analisis mediasi multikategorikal menunjukkan bahwa kecemasan, optimisme, ketakutan akan kematian dan isolasi sosial secara signifikan memediasi efek usia pada perilaku protektif. Secara khusus, kecemasan dan ketakutan akan kematian meningkatkan perilaku protektif melalui persepsi risiko yang lebih tinggi pada kelompok usia paruh baya dan yang lebih muda. Optimisme secara langsung memprediksi perilaku protektif pada kelompok paruh baya, sementara isolasi sosial mengurangi perilaku protektif pada kelompok usia lebih muda dan lebih tua ${ }^{19}$ sementara di Prancis menunjukkan usia lebih tua lebih bersedia untuk menerima vaksinasi Covid $19^{2}$.

Lebih dari 85\% kematian akibat Covid-19 di negara berpenghasilan tinggi terjadi pada orang berusia 65 tahun atau lebih. Data terpilah baru-baru ini dari Inggris dan AS menunjukkan bahwa kematian komunitas minoritas telah meningkatkan di antara kelompok usia yang lebih muda. Di Afrika Selatan data awal menunjukkan bahwa mayoritas kematian akibat Covid-19 berusia di bawah 65 tahun. Pengamatan ini menunjukkan potensi signifikan untuk peningkatan kematian Covid-
19 di antara populasi yang lebih muda di Afrika dan Asia Selatan dan dapat memengaruhi pemilihan berdasarkan usia dari kelompok berisiko tinggi yang memenuhi syarat untuk mendapatkan vaksin di masa depan ${ }^{12}$.

Individu berusia 20 hingga 49 tahun adalah satu-satunya kelompok usia yang mengalami penularan SARS-CoV-2 kembali dengan jumlah reproduksi jauh di atas satu dan bahwa setidaknya 65 dari 100 infeksi Covid-19 berasal dari individu berusia 20 hingga 49 tahun di Amerika Serikat. Menargetkan intervensi, termasuk vaksin yang mencegah penularan kepada orang dewasa berusia 20 hingga 49 tahun merupakan pertimbangan penting dalam menghentikan epidemi yang muncul kembali dan mencegah kematian akibat Covid- $19^{20}$. Vaksinasi anak dan dewasa muda, kematian secara keseluruhan tidak akan berkurang secara substansial kecuali vaksin secara langsung dapat melindungi orang tua ${ }^{21}$.

Agama juga menjadi faktor kunci dari kesediaan masyarakat Sulawesi Tengah untuk menerima vaksinasi Covid-19. Oleh karena OR faktor agama $=0,402(0.241-0.670)$ ini berarti agama adalah faktor determinan protektif kesediaan masyarakat Sulawesi Tengah menerima vaksinasi Covid-19. Berdasarkan studi Al-Mohaithef M di Arab Saudi, responden yang tertarik untuk divaksinasi Covid-19 adalah mereka yang warga non-Saudi Arabia ${ }^{12}$, ketahui warga Saudi Arabia adalah dominan muslim. Tanggapan Muslim terhadap virus ini dapat dikategorikan menjadi setidaknya lima tipologi. Kelima tipologi tersebut adalah irasional-pasif, irasional-aktif-pembenci, semi-rasionalsuportif, rasional-malu-malu, dan rasionalaktif-suportif. Kelima kategori tersebut dipengaruhi oleh latar belakang pendidikan, kehidupan sosial, budaya, ekonomi, pemahaman agama, dan komitmen beragama ${ }^{22}$. Analisis Jardine (2020) menunjukkan keragaman yang luas dalam tanggapan Covid19 di negara-negara mayoritas Muslim dengan indikasi yang jelas bahwa demokrasi fungsional mampu menahan epidemi secara signifikan lebih baik daripada rezim non-demokrasi ${ }^{23}$.

Terkait dengan masih rendahnya responden yang bersedia menerima vaksinasi Covid-19 (35,3\%) di Sulawesi Tengah dan responden yang beragama Islam yang bersedia 
menerima vaksin juga hanya $30,7 \%$. Menunjukkan bahwa masih perlu sosialisasi yang lebih mendalam untuk keberhasilan pelaksanaan vaksinasi di Sulawesi Tengah.

Pengetahuan dan pemahaman publik yang kurang tentang sosialisasi Covid-19. Sosialisasi kebijakan ulama belum berjalan efektif, seperti terlihat pada beberapa kasus, seperti penolakan penutupan masjid dan pelarangan kegiatan keagamaan lainnya, akibat minimnya pengetahuan masyarakat tentang wabah ini. Kebijakan pemerintah tentang pembatasan sosial skala besar yang didukung penuh oleh majelis ulama Indonesia sebagai representasi ulama Indonesia belum mampu menekan semangat masyarakat muslim dalam menjalankan kegiatan keagamaan. Hal tersebut menunjukkan otorisasi ulama dalam melawan pandemi Covid-19 bagi masyarakat muslim di Indonesiarendah ${ }^{24}$.

Seiring dengan efek ekonomi dan sosial global yang tak tertandingi, pandemi Covid-19 telah menimbulkan tantangan signifikan bagi kesehatan masyarakat di seluruh dunia ${ }^{25}$, untuk mencegah penularan, kita harus tetap berhatihati dan berharap berita tentang vaksin yang berhasil $^{26}$. Setelah aspek biologis dan teknis dari pengembangan dan pembuatan vaksin tercapai, manfaat yang diberikan pada kesehatan populasi juga akan bergantung pada kemauan publik untuk vaksinasi. Hal ini membantu individu membuat keputusan yang tepat tentang penggunaan vaksin ${ }^{27}$. Beberapa efek samping dari vaksin covid-19 adalah nyeri tempat suntikan ringan sampai sedang, kelelahan, dan sakit kepala, insiden kejadian efek samping yang serius pada kelompok vaksin dan plasebo kecil dan serupa ${ }^{28}$.

Penelitian ini menunjukkan bahwa responden memperoleh informasi tentang Covid-19 melalui televisi 53,8\%, facebook $(27,4 \%)$ dan Instagram (23,7\%). Responden memperoleh informasi lebih banyak dari media televisi kemudian dari facebook dan Instagram. Media ini dapat menjadi pilihan untuk menyampaikan sosialisasi terkait dengan keamanan dan efektifitas vaksin.

Media sosial, keluarga, teman dan promosi dikaitkan secara negatif dengan keamanan vaksin $^{29}$. Penggunaan media sosial untuk mengatur tindakan offline sangat memprediksi keyakinan bahwa vaksinasi tidak aman. Prevalensi disinformasi asing signifikan dalam memprediksi penurunan cakupan vaksinasi. Efek substantif asing, disinformasi adalah meningkatkan jumlah tweet vaksin negatif sebesar $15 \%^{30}$. Advokasi untuk vaksin Covid19 idealnya harus dipimpin oleh komunitas lokal dan pendukung komunitas, akses terhadap vaksin harus diprioritaskan secara transparan untuk mereka yang paling berisiko, bisnis, serikat pekerja, komunitas agama, amal, media, hiburan, dan olahraga adalah kuncinya ${ }^{31}$.

Rencana vaksinasi massal akan mengatasi hambatan potensial untuk adopsi luas melalui kampanye pendidikan, Vaksin untuk segera diberikan kepada publik segera setelah kemanjuran dan keamanan terbukti ${ }^{32}$. Pekerjaan untuk mempersiapkan publik untuk pengendalian vaksin pandemi ini perlu dimulai sekarang, harus ada advokasi untuk vaksin Covid-19 idealnya dipimpin oleh komunitas lokal dan komunitas pusat, ketersediaan vaksin harus ditransformasikan diprioritaskan secara parsial bagi mereka yang berisiko tinggi, akses ke vaksin harus melalui pengaturan yang sudah dikenal misalnya ke apotek dan supermarket kelas atas dan tidak hanya di klinik kesehatan dan rumah sakit. Akhirnya, kepemimpinan program vaksin nasionalharus dibagikan di luar pemerintah dan badan kesehatan masyarakat, strategi vaksinasi Covid-19 menuntut respons seluruh masyarakat termasuk dunia bisnis, serikat buruh, komunitas keagamaan,amal, media, hiburan, dan olahraga dengan fokus pada kelompok umur dewasa muda dan beragama Islam.

\section{KESIMPULAN DAN SARAN}

Sebagian besar responden di Sulawesi Tengah menyatakan bahwa vaksin Covid-19 aman dan efektif, namun responden yang bersedia menerima vaksinasi Covid-19 hanya sebesar 35,3\%. Faktor yang mempengaruhi kesediaan masyarakat menerima vaksinasi adalah faktor umur, tingkat pendidikan, pekerjaan, status pernikahan, agama dan suku. Determinan protektif kesediaan masyarakat menerima vaksinasi Covid-19 adalah umur dan agama. Disarankan agar sosialisasi untuk divaksinasi Covid-19 fokus pada orang dengan kelompok umur $\leq 40$ tahun dan beragama 
Islam, sosialisasi vaksinasi Covid-19 melalui televisi dan media sosial facebook dan Instagram, oleh satgas Covid-19, Badan Pengawas Obat dan Makanan dan Kementerian Kesehatan.

\section{UCAPAN TERIMA KASIH}

Terimakasih diucapkan kepada Kepala Badan POM di Palu, Direktur Poltekkes Kemenkes Palu dan kepada semua responden penelitian yang telah berpartisipasi mengisi link pendataan yang dibagikan secara online

\section{DAFTAR PUSTAKA}

1. Ko SC. Herd immunity, vaccine development and BCG effects in COVID19. J Intern Med Taiwan [Internet]. 2020;31(4):254-61. Available from: http://www.tsim.org.tw/journal/jour314/04.PDF

2. Detoc M, Bruel S, Frappe P, Tardy B, Botelho-Nevers E, Gagneux-Brunon A. Intention to participate in a COVID-19 vaccine clinical trial and to get vaccinated against COVID-19 in France during the pandemic. Vaccine [Internet]. 2020 Oct;38(45):7002-6. Available from: https://linkinghub.elsevier.com/retrieve/pii/ S0264410X20312019

3. Pasaribu TAA. Persepsi Masyarakat Tentang Covid 19. 2021; Available from: https://osf.io/qbjmt

4. Reiter PL, Pennell ML, Katz ML. Acceptability of a COVID-19 vaccine among adults in the United States: How many people would get vaccinated? Vaccine [Internet]. $2020 \quad$ Sep;38(42):6500-7. Available from: https://linkinghub.elsevier.com/retrieve/pii/ S0264410X20310847

5. Harrison EA, Wu JW. Vaccine confidence in the time of COVID-19. Eur J Epidemiol [Internet]. 2020 Apr 22;35(4):325-30. Available from: http://link.springer.com/10.1007/s10654020-00634-3

6. Ding Y, Du X, Li Q, Zhang M, Zhang Q, Tan X, et al. Risk perception of coronavirus disease 2019 (COVID-19) and its related factors among college students in China during quarantine. Yi S, editor. PLoS One [Internet]. 2020 Aug 13;15(8):e0237626. Available from: https://dx.plos.org/10.1371/journal.pone.02

\section{6}

7. Zhu F-C, Guan X-H, Li Y-H, Huang J-Y, Jiang T, Hou L-H, et al. Immunogenicity and safety of a recombinant adenovirus type-5vectored COVID-19 vaccine in healthy adults aged 18 years or older: a randomised, double-blind, placebo-controlled, phase 2 trial. Lancet [Internet]. 2020 Aug;396(10249):479-88. Available from: https://linkinghub.elsevier.com/retrieve/pii/ S0140673620316056

8. Iserson, V K. SARS-CoV-2 (COVID-19) Vaccine Development and Production: An Ethical Way Forward. Cambridge Q Healthc Ethics [Internet]. 2021 Jan 5;30(1):59-68. Available from: https://www.cambridge.org/core/product/id entifier/S096318012000047X/type/journal_ article

9. Danchin M, Biezen R, Manski-Nankervis JA, Kaufman J, Leask J. Preparing the public for COVID-19 vaccines: How can general practitioners build vaccine confidence and optimise uptake for themselves and their patients? Aust J Gen Pract [Internet]. 2020 Oct 1;49(10):625-9. Available from: https://www1.racgp.org.au/ajgp/2020/octob er/preparing-the-public-for-covid-19-

vaccines

10. Febriyanti N, Choliq MI, Mukti AW. Hubungan Tingkat Pengetahuan dan Kesediaan Vaksinasi Covid-19 pada Warga Kelurahan Dukuh Menanggal Kota Surabaya. SNHRP [Internet]. 2021; Available from: https://snhrp.unipasby.ac.id/prosiding/index .php/snhrp/article/view/168

11. Chew P. COVID-19 Vaccination Education App(1). In: SSRN Electronic Journal [Internet]. papers.ssrn.com; 2021. Available from:

https://papers.ssrn.com/sol3/papers.cfm?abs tract_id=3842490

12. Al-Mohaithef M, Padhi BK. Determinants of COVID-19 Vaccine Acceptance in Saudi Arabia: A Web-Based National Survey. J Multidiscip Healthc. 2020;(13):1657-63.

13. Guhlincozzi AR, Lotfata A. Travel distance to flu and COVID-19 vaccination sites for people with disabilities and age 65 and older, Chicago metropolitan area. J Heal Res [Internet]. 2021 May 13; ahead-of-p(aheadof-print). Available from: https://www.emerald.com/insight/content/d oi/10.1108/JHR-03-2021-0196/full/html

14. Sultana F, Mahmud Reza H. Are SAARC 
countries prepared to combat COVID-19 to save young, working-age population? AIMS Public Heal. 2020;7(3):440-9.

15. Malmgren J, Guo B, Kaplan HG. Continued proportional age shift of confirmed positive COVID-19 incidence over time to children and young adults: Washington State March-August 2020. Borrow R, editor. PLoS One [Internet]. 2021 Mar 24;16(3):e0243042. Available from: https://dx.plos.org/10.1371/journal.pone.02 43042

16. MacIntyre CR, Cauchemez S, Dwyer DE, Seale H, Cheung P, Browne G, et al. Face Mask Use and Control of Respiratory Virus Transmission in Households. Emerg Infect Dis [Internet]. 2009 Feb;15(2):233-41. Available from: http://wwwnc.cdc.gov/eid/article/15/2/081167_intro.htm

17. Wong $\mathrm{SH}$, Teoh JYC, Leung $\mathrm{C}-\mathrm{H}$, Wu WKK, Yip BHK, Wong MCS, et al. COVID-19 and Public Interest in Face Mask Use. Am J Respir Crit Care Med [Internet]. 2020 Aug 1;202(3):453-5. Available from: https://www.atsjournals.org/doi/10.1164/rc cm.202004-1188LE

18. Zou L, Ruan F, Huang M, Liang L, Huang H, Hong Z, et al. SARS-CoV-2 Viral Load in Upper Respiratory Specimens of Infected Patients. N Engl J Med [Internet]. 2020 Mar 19;382(12):1177-9. Available from: http://www.nejm.org/doi/10.1056/NEJMc2 001737

19. Pasion R, Paiva TO, Fernandes C, Barbosa F. The AGE Effect on Protective Behaviors During the COVID-19 Outbreak: Sociodemographic, Perceptions and Psychological Accounts. Front Psychol [Internet]. 2020 Oct 16;11. Available from: https://www.frontiersin.org/article/10.3389/ fpsyg.2020.561785/full

20. Monod M, Blenkinsop A, Xi X, Hebert D, Bershan S, Tietze S, et al. Age groups that sustain resurging COVID-19 epidemics in the United States. Science (80- ) [Internet]. 2021 Mar 26;371(6536):eabe8372. Available from: https://www.sciencemag.org/lookup/doi/10. 1126/science.abe8372

21. Sadarangani M, Abu Raya B, Conway JM, Iyaniwura SA, Falcao RC, Colijn C, et al. Importance of COVID-19 vaccine efficacy in older age groups. Vaccine [Internet]. 2021 Apr;39(15):2020-3. Available from: https://linkinghub.elsevier.com/retrieve/pii/
S0264410X21002887

22. Husni H, Bisri H, Tanto Aljauharie Tantowie SSR, Azis A. Religious Community Responses to COVID-19: Case Study on Muslim Small Community. Int J Psychosoc Rehabil [Internet]. 2020;24(8):10439-46. Available from: http://digilib.uinsgd.ac.id/id/eprint/31190

23. Jardine R, Wright J, Samad Z, Bhutta ZA. Analysis of covid-19 burden, epidemiology and mitigation strategies in muslim majority countries. East Mediterr Heal J. 2020;26(10):1173-83.

24. Pabbajah M, Said NM, Faisal, Taufiq Hidayat Pabbajah M, Jubba H, Juhansar. Deauthorization of the religious leader role in countering covid- 19: Perceptions and responses of muslim societies on the ulama's policies in indonesia. Int J Criminol Sociol. 2020;9:262-73.

25. Brown S, Brown T, Cederna PS, Rohrich RJ. The Race for a COVID-19 Vaccine: Current Trials, Novel Technologies, and Future Directions. Plast Reconstr Surg - Glob Open. 2020;1-14.

26. Hillard PJA. COVID, Science, Vaccines, and Public Trust. J Pediatr Adolesc Gynecol [Internet]. 2020 Dec;33(6):617-8. Available from:

https://linkinghub.elsevier.com/retrieve/pii/ S1083318820303533

27. Basch CH, Hillyer GC, Zagnit EA, Basch CE. YouTube coverage of COVID-19 vaccine development: implications for awareness and uptake. Hum Vaccin Immunother [Internet]. 2020 Nov 1;16(11):2582-5. Available from: https://www.tandfonline.com/doi/full/10.10 80/21645515.2020.1790280

28. Polack FP, Thomas SJ, Kitchin N, Absalon J, Gurtman A, Lockhart S, et al. Safety and Efficacy of the BNT162b2 mRNA Covid-19 Vaccine. N Engl J Med [Internet]. 2020;2603-15. Available from: http://www.ncbi.nlm.nih.gov/pubmed/3330 1246

29. Hwang J. Health Information Sources and the Influenza Vaccination: The Mediating Roles of Perceived Vaccine Efficacy and Safety. J Health Commun [Internet]. 2020 Sep 1;25(9):727-35. Available from: https://www.tandfonline.com/doi/full/10.10 80/10810730.2020.1840675

30. Wilson SL, Wiysonge C. Social media and vaccine hesitancy. BMJ Glob Heal [Internet]. $2020 \quad$ Oct;5(10):e004206. 
Available

from: https://gh.bmj.com/lookup/doi/10.1136/bmj gh-2020-004206

31. Horton R. Offline: Preparing for a vaccine against COVID-19. Lancet [Internet]. 2020 Jul;396(10246):226. Available from: https://linkinghub.elsevier.com/retrieve/pii/ S0140673620316366
32. Al Awaidy ST, Khamis F. Preparing the Community for a Vaccine Against COVID19. Oman Med J [Internet]. 2020 Nov 15;35(6):e193-e193. Available from: http://omjournal.org/articleDetails.aspx?co Type $=1 \&$ aId $=2774$ 